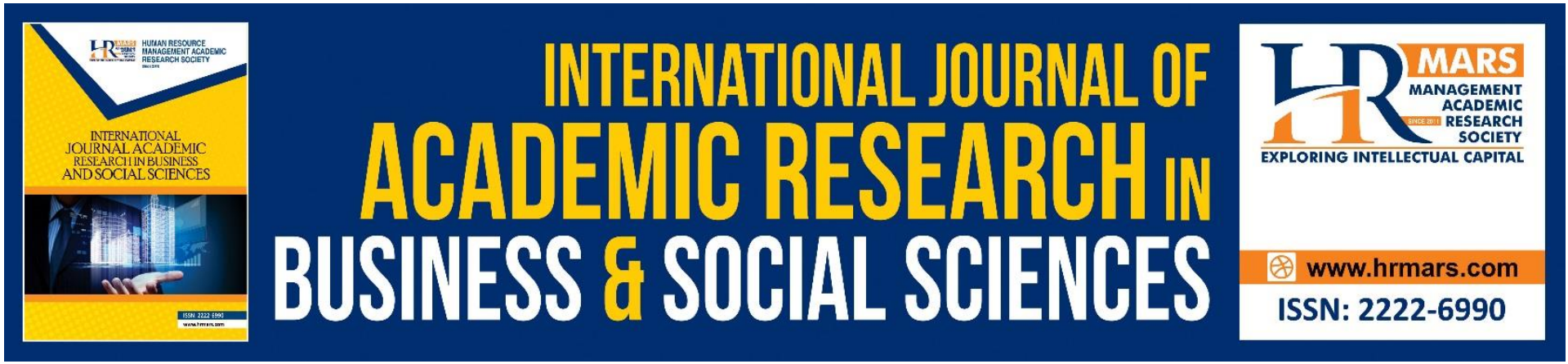

\title{
The Challenges in Implementation of Ethics in Organization
}

Syuhaidah Abdul Rahman, Norhayati Hussin, Jannatul Iza Ahmad Kamal, Norsaniah Md Noh, Siti Nurul Maryam Abdullah, Zahari Mohd Amin

To Link this Article: http://dx.doi.org/10.6007/IJARBSS/v10-i11/8195 DOI:10.6007/IJARBSS/v10-i11/8195

Received: 17 September 2020, Revised: 15 October 2020, Accepted: 10 November 2020

Published Online: 28 November 2020

In-Text Citation: (Abdul Rahman, et. al., 2020)

To Cite this Article: Abdul Rahman, S., Hussin, N., Kamal, J. I. A., Noh, J. I. A., Abdullah, S. N. M., Amin, Z. M. (2020). The Challenges in Implementation of Ethics in. International Journal of Academic Research in Business and Social Sciences. 10(11), 1187-1194.

Copyright: (c) 2020 The Author(s)

Published by Human Resource Management Academic Research Society (www.hrmars.com) This article is published under the Creative Commons Attribution (CC BY 4.0) license. Anyone may reproduce, distribute, translate and create derivative works of this article (for both commercial and non-commercial purposes), subject to full attribution to the original publication and authors. The full terms of this license may be seen at: http://creativecommons.org/licences/by/4.0/legalcode

Vol. 10, No. 11, 2020, Pg. 1187 - 1194

Full Terms \& Conditions of access and use can be found at http://hrmars.com/index.php/pages/detail/publication-ethics 


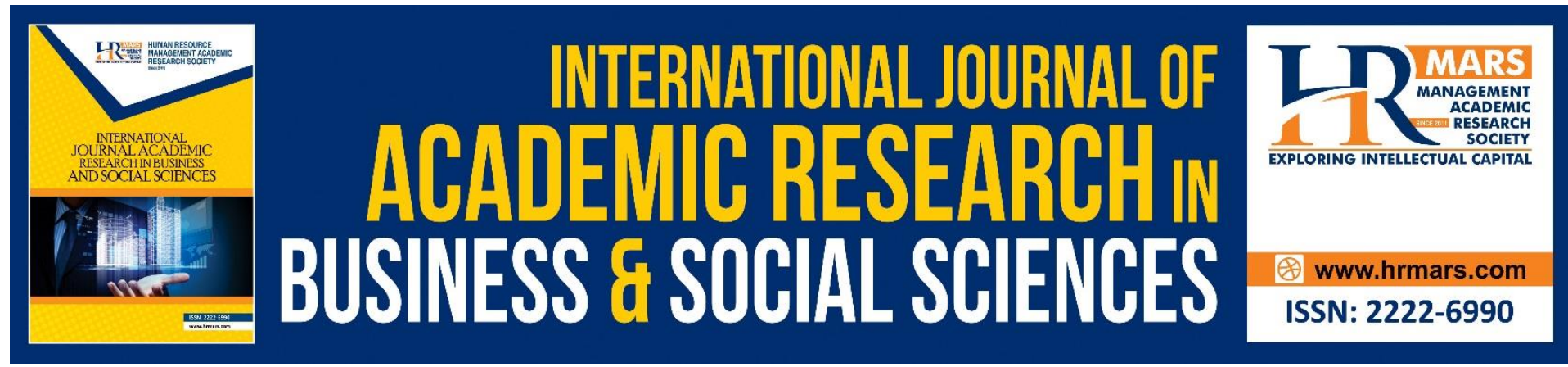

\title{
The Challenges in Implementation of Ethics in Organization
}

\author{
Syuhaidah Abdul Rahman, Norhayati Hussin, Jannatul Iza \\ Ahmad Kamal, Norsaniah Md Noh, Siti Nurul Maryam Abdullah, \\ Zahari Mohd Amin \\ Faculty of Information Management, Universiti Teknologi MARA (UiTM) Selangor, Malaysia
}

\begin{abstract}
This paper is report of study that looks at the challenges in implementation of ethics in organization. The study reveals that organization become inefficient and ineffective as a result of lack in ethics practices. Leader plays crucial sources as ethical guidance to the employee as well as show the ethical responsibility for a moral development in organization. However, leaders and human resources department did not see ethics as a crucial part in working environment. Besides that, the ethics training program also important platform to provide knowledge and education to employee and leader regarding the ethical issues and solution related with the issues. Based on previous study, this paper also identify several componence for ethics program in the organization. The conclusions drawn that leaders has not yet been professionalized. The paper then discuss what are challenges faced by the organization nowadays in order for them to change and improve in future.
\end{abstract}

Keywords: Library and Information Management, Ethics in Organizations, Information Management Challenges.

\section{Introduction}

According to Reynolds (2019), ethics is a code of behaviour that is defined by the group to which an individual belongs. Ethical behaviour conforms to generally accepted norms, which may change over time to meet the evolving needs of the society or a group of people who share similar laws, traditions and values that provide structure to enable them to live in an organized manner. Ethics help members of a group understand their roles and responsibilities in order to enable them to work together to achieve mutual benefits such as security, access to resources and the pursuit of life goals (Reynolds, 2019). Despite researcher writing about indicators of ethics effectiveness, actually, there are many challenges in the implementation of ethics in the organization. It involves a lack of enforcement, organizational culture, poor leadership, whistleblowing and lack of ethics training.

\section{Lack of Enforcement}

Nowadays, compliance has been addressed as a factor that increases the efficacy of codes, but it needs to be looked at from the traditional theory viewpoint, including not only punishment but also incentives. A person's willingness to engage in ethical or unethical 
behaviour can influence the recorded acts. Consequently, it was found that the capacity for unethical behaviour is a better predictor of actions than social or belief. It has been shown that employees work harder to understand and follow the ethical values and strategies of top management if the organization rewards people for following excellent ethical standards while also punishing those who do not behave ethically. Examples of moral behaviour incentives are recognition, appreciation, recognition, and money. Human resources department has these direct and indirect control mechanisms, organizations with equal reward systems, promoting ethical behaviour and implementing a consistent compliance process are likely to have a positive effect on ethical attitudes and behaviours (Mcdonald, 2009). Askew, Beisler \& Keel (2015) state by establishing and enforce the code of conduct or ethics will assist in create the organization environment that encourage the ethical behavior among people.

\section{Organizational Culture}

Organizational culture can be identified as the beliefs and behaviours that contribute to the social and psychological atmosphere unique to an organization. While, Rick (2015) state organisational culture represents the system of shared assumption, values and belief which related to governing how people behave in the organization. Organisation culture is one of strategic asset towards improving the performance of the organization itself. It also involves an organization's objectives, values, philosophy, and convictions that tie it together, and is expressed in its self-image, internal workings, public relations, and expectations for the future. It is based on common attitudes, values, customs and written and unwritten rules that have been developed over time and are considered valid (Business Dictionary, 2019).

Actually, for ethical decision-making and coding help, organizational culture also plays a role. Previous research indicated that the organization who have high morals and is ethically based on their image, their employee will show the behavior in suitable responsible manner (Erwin, 2011). Corporate culture as a multi-dimensional phenomenon can be challenging, and often a perceptional indicator of the quality of one's organizational culture needs to be combined with a value congruence metric. Therefore, when evaluating the influence of the corporate culture of an organization on ethical decision-making, it is not enough simply to ask for judgment on the perceived strength of the corporate culture. It is also necessary to obtain data on the alignment of personal values with the values of the organization found in that culture and the stress they may face. The factor of organizational stress is closely related to the structure of incentives. While initially intended to represent external organizational factors such as market control and scarcity of resources, enforcement stress is a potential outcome of ethical conflict when the personal business ethics of an employee is inconsistent with the organization's ethical standards (McDonald, 2009).

McDonald (2009) also stated that differential association theory posts that a person tends to follow the actions and beliefs of those with whom he communicates, depending on the relationship of individual contacts. They also concluded that, without internalizing group standards, an individual can act according to group pressure. Several additional institutional approaches have been proposed to improve the ethical environment and promote principles of the social element, such as improving employee appraisal processes, performing ethical reviews, protecting whistleblowers, improved strategic planning of the judiciary committee, and education in ethics. In addition to ethical codes as a way of institutionalizing morality, organization have made systemic and organizational improvements such as the introduction of ombudsmen's ethics, ethical committees and newsletters on ethics. 


\section{Poor Leadership}

Comprehensions and reactions of a leader to ethical codes have been a mediating influence code and their application, and research strongly supports the conclusion that ethical philosophies and management principles have a significant impact on employee ethical choices and behaviour. Employees assume that unethical behaviour is dependent on the organizational environment, particularly the immediate action of one's boss and peers. As a result, the management position has been extensively studied, suggesting that the perceived attitudes and actions of immediate subordinates and senior managers are significantly affected by employees ' unethical decisions (Mcdonald, 2009). Mihelič, Lipičnik and Tekavčič (2010) state leader especially the crucial sources of ethical guidance to the employee as well as show the ethical responsibility for a moral development in organization.

Given the significant impact of corporate governance on both ethical and unethical behaviour, despite all the good work that goes into creating rules, it seems that they can be relatively easily undermined and improved due to the attitudes and behaviours of managers and members of the organization. It is therefore not important to rely on the code itself in order to achieve ethical results since its effect can be mitigated by countering the prevalence of senior positions ' views and actions (Mcdonald, 2009). The senior view and action will influence the employee action especially on ethical and unethical behavior. Inappropriate modelling organizational leadership, setting unrealistic and unattainable target, lack of trust within organization, support unethical act within organization and weal of legal and policies related with ethics is some factor that contribute towards unethically conducted by the organization leadership (Kabeyi, 2018). Other than that, unethical business leader also use one set of standard in work place while applying another set of standard for personal profit even though the legal system will prosecute person who found guilty and unethical misconduct (Franks \& Spalding, 2013; Pendse, 2012). These is some of the character of unethical leader who character possess unethical behavior. So, Prentice (2014) state it is necessary to strengthen the moral reasoning and reinforcing character in assisting the leader who wish to be better people and also who wish other people to be ethical leadership.

\section{Whistleblowing}

Whisleblowing system has attracted the world attention because many big company who cheating has been revealed (Pangmungkas, Ghozali \& Achmad (2017)). Whistleblowing is an effort to attract public attention to a negligent, illegal, unethical, abusive or dangerous act by an individual or organization. Other than that, whistleblowers are employees who act as informants on their organization, revealing information to enrich themselves or to gain revenge for a perceived wrong. However, whistleblowers act ethically in an attempt to correct what they think is major wrongdoing, often at great personal risk (Reynolds, 2019).

Whistleblowers start as people who sympathize with the system and are committed to their work and organizations. They change their views and then only face reprisals if they are forced to breach their own ethical, moral standards. An organization that constantly silences or eliminates its loyal heresies is a system on its way to failure. It is not ethically responsive to one who does not provide an adequate internal support system for their loyal whistles blowing due to a breach of professional standards (Ray, 2006).

According to Ray (2006), transparency in the public and private sectors, the agency and the health care professional, and the health care worker and the client are at the heart of the issue of whistleblowing. Health care organizations need to pursue a concerted plan to create an ethical infrastructure in order to prevent a collapse in transparency. The lack of internal 
resources, interaction and value structures are major factors in issues leading to public whistleblowing. They need to create ethical health care organizations with adequate procedures in place to encourage responsibly, committed, loyal heretics to address ethical issues openly. Therefore, improvements are needed to build ethical infrastructure in order to develop a positive society's.

Failure to respond to internal whistleblowing was an institution that was ethically corrupted in its heart and lost its moral compass. Unethical behaviour in health care institutions is more systemic and traceable to institutional structures than to the in dividual moral failures in which it arises. A bureaucracy is capable of mechanizing virtually every aspect of human life, eroding man's spirit and the ability to act spontaneously. A hierarchical administrative structure can reproduce the social class system in which the use of the human resources department or force people into a process of dominance. In the nursing literature, on the other hand, workplace bullying and public harassment of nurses who they are supporters or whistleblowers they are all documented. In this type of environment, nurses who are unable to obey uniform, team standards or organization culture procedures may be forced to change jobs or even careers (Ray, 2006).

\section{Lack of Ethics Training}

Establishing an ethical culture remains a challenge for all international organization, and is one that plays a central role for human resources professionals. In view of high-profile harassment cases involving businesses that, despite having an ethical policy or code, have suffered almost catastrophic hits to credibility, it is clear that it is not enough to have an ethical code and to expect that workers can read it, grasp it and apply it human resources throughout their everyday working lives (Irwin and Bradshaw, 2011; Christou \& Stamou, 2013).

Irwin and Bradshaw (2011) stated that human resources departments are a point of contact within an organization for all workers. They have unprecedented access to workers from induction training to exit interviews and can be critical for all roles to create a cohesive workplace culture. Establishing good business standards based on ethical principles allows businesses to enforce ethics or corporate responsibility policies such as laws, guidelines, training and support, and so on, as they are all as to foster an ethical culture effectively. One way international organization can ensure that their ethics programs are both appropriate and effective is to create a network of ambassadors of ethics to help promote the ethical values, policies and programs of the organization.

A code of ethics includes various components, including training, a communication strategy, and a protocol for speaking up. In addition, Kaptein (2015) state the best sequence for ethical component program is $s(1)$ a code of ethics, (2) ethics training and communication, (3) accountability policies, (4) monitoring and auditing, and (5) investigation and correction policies (6) an ethics office(r), (7) ethics report line, and (8) incentive policies. Other than that, the organization also can implement business ethics which formal learning space where the employee will expose to the various type of high-principle dilemmas in organization (Fatin Erna Mat Arif, Zulaikha Zulkefli and Norhayati Hussin, 2017). It can be a complex and lengthy process that requires attention, persistence, and energy to integrate business conduct ethical principles across an enterprise actually to influence culture, decision-making, and actions. Creating ambassadors of ethics is an ideal way of human resources department to a global organization to incorporate the different elements of such a program (Irwin and Bradshaw, 2011). Besides that, ethical failure of organizational leadership also have led to interest in 
promoting ethical conduct and developing ethical leaders (Chikeleze \& Baehrend, 2017). There are assessment been create by previous researcher in solving this issues. This may become guideline to leader in the organization.

Human resources departments are placed in a unique position to express this in an organization. Ethics can be granted authority in human resources and adapted to the way the organization works. Improve the senior position or manager ability to handle ethical issues workplace will enhance professional development initiatives that provide by human resource department (Romious, Thompson \& Thompson, 2016). Human resources department is responsible for key systems and processes that can support the effective delivery of ethical messages that the organization wishes to communicate. Human resources practitioners may assist in incorporating ethics into processes such as employer brand, hiring, promotion, evaluation, retention, encouragement, incentive, diversity, coaching and learning by working in collaboration with those responsible for ethical quality in their organization (Irwin and Bradshaw, 2011). Besides that, developing the skill set also will able the employee analyze and deal with the ethical issues in order to make a good decision and navigate ethical challenges is a part of training should implement in the organization (Ahadi, 2020).

\section{Conclusion}

In conclusion, ethics is important because it meets basic human needs when every employee wants to be and work for a fair and ethical organization in their practices. An organization considered to be motivated by moral values is respected even by those in society who may have little understanding of the job and the business or organization. His workers also respect a value-driven organization. These are the typical human resources on a single network that puts workers and decision-makers. This goes a long way to achieving a common goal or mission of matching behaviours within the organization. Besides that, organizations driven by ethics and values are long-term efficient, although they may seem to lose money in the short run. Ethics is also working to protect society by legislation. As a silent observer, the law system is often found to be behaving, unable to save community and the world. Technology, for instance, is growing at such a rapid pace that they will have a new technology and new human resources that will replace the older one when the rule comes up. In short, ethics tries to create a sense of right and wrong in organizations, and often when the law fails, it is the ethics that can prevent organizations from harming society or the environment (Juneja, 2019).

\section{Acknowledgement}

This article is financially supported by:

1. Faculty of Information Management, UiTM Selangor, Malaysia

\section{Corresponding Author}

Norhayati Hussin.

Faculty of Information Management, Universiti Teknologi MARA (UiTM) Selangor,

Malaysia.

Email: yatihussin@uitm.edu.my

\section{References}

Askew, O. A., Beisler, J. M., \& Keel, J. (2015). Current trends of unethical behavior within organizations. International Journal of Management \& Information Systems (IJMIS), 19(3), 107-114. 
Ahadi, S. (2020). Training Employees To Act Ethically—What Is Missing?. Retrieved April 2020, from: https://trainingmag.com/training-employees-act-ethically-what-missing/

Business Dictionary. (2019). Definition of organizational culture. Retrieved from http://www.businessdictionary.com/definition/organizational-culture.html

Chikeleze, M. C., \& Baehrend Jr, W. R. (2017). Ethical Leadership Style and Its Impact on Decision-Making. Journal of leadership studies, 11(2), 45-47.

Christou, S., \& Stamou, A. G. (2013). Representations of military sociolect in Greek cinema. Multilingual Academic Journal of Education and Social Sciences, 1(2), 40-58.

Erwin, P. (2011). Corporate codes of conduct: The effects of code content and quality on ethical performance. Journal of Business Ethics, 99(4), 535. doi:10.1007/s10551-0100667-y

Franks, R., \& Spalding, A. (2013). Business ethics as an accreditation requirement: A knowledge mapping approach. Business Education \& Accreditation, 5(1), 17-30.

Irwin, J., \& Bradshaw, K. (2011). The ethics challenge: Establishing an ethics ambassador network to help embed an ethical culture. Strategic HR Review, 10(4), 26-32. Retrieved from

https://www-emeraldcom.ezaccess.library.uitm.edu.my/insight/content/doi/10.1108/1475439111114097 $2 /$ full/html

Juneja, P. (2019). Importance of ethics. Retrieved from https://www.managementstudyguide.com/importance-of-ethics.htm

Kaptein, M. (2015). The effectiveness of ethics programs: The role of scope, composition, and sequence. Journal of Business Ethics, 132(2), 415-431.

Kabeyi, J. B. M. (2018). Ethical and unethical leadership issues, cases, and dilemmas with case studies. International Journal of Applied Research 2018; 4(7): 373-379.

Mihelič, K. K., Lipičnik, B., and Tekavčič, M. (2010). Ethical Leadership. International Journal of Management \& Information Systems - Fourth Quarter 2010, 4 (5). pp 31 - 42.

Mcdonald, G. M. (2009). An anthology of codes of ethics. European Business Review, 21(4), 344-372. Retrieved from: https://www-emeraldcom.ezaccess.library.uitm.edu.my/insight/content/doi/10.1108/0955534091097044 $5 /$ full/html

Pamungkas, I. D., Ghozali, I., \& Achmad, T. (2017). The effects of the whistleblowing system on financial statements fraud: Ethical behavior as the mediators. International Journal of Civil Engineering and Technology, 8(10), 1592-1598.

Ray, S. L. (2006). Whistleblowing and organizational ethics. Nursing Ethics, 13(4), 438-445. Retrieved from: https://journals-sagepubcom.ezaccess.library.uitm.edu.my/action/doSearch?filterOption=allJournal\&AllField $=$ WHISTLEBLOWING+AND+ORGANIZATIONAL+ETHICS

Romious, T. S., Thompson, R., \& Thompson, E. (2016). Ethics Training and Workplace Ethical Decisions of MBA Professionals. Journal of Education and Learning, 5(1), 190-198.

Reynolds, G. W. (2019). Ethics in information technology (6th ed.). Boston: Cengage Learning, Inc.

Rick, T. (2015). What is organizational culture. Corporate Culture, Organization Development. Retrieved November 2019, from: https://www.torbenrick.eu/blog/culture/organizational-culture/

Pendse, S. G. (2012). Ethical hazards: A motive, means, and opportunity approach to curbing unethical behavior. Journal of Business Ethics, 107, 265-279. http://dx.doi.org/10.1007/s10551-011-1037-0 
INTERNATIONAL JOURNAL OF ACADEMIC RESEARCH IN BUSINESS AND SOCIAL SCIENCES

Vol. 10 , No. 11, 2020, E-ISSN: $2222-6990$ @ 2020 HRMARS

Prentice, R. (2014). Teaching behavioral ethics. Journal of Legal Studies Education. 2014; 31(2):325-365. 